\title{
Design and Development of Bi-layered Sustained Release Azithromycin Tablets
}

\author{
Muhammad Rashedul Islam ${ }^{1}$, Md. Mizanur Rahman Moghal' ${ }^{2}$, \\ F.M. Shah Noman UI Bari ${ }^{3}$ and Elias AI Mamun ${ }^{1}$
}

\author{
${ }^{1}$ Department of Pharmaceutical Technology, University of Dhaka, Dhaka-1000, Bangladesh \\ ${ }^{2}$ Department of Pharmacy, MawlanaBhashani Science and Technology University, Santosh, Tangail-1902, \\ Bangladesh \\ ${ }^{3}$ Department of Pharmacy, Noakhali Science and Technology University, Noakhali-3814, Bangladesh
}

(Received: December 2, 2016; Accepted: December 18, 2016; Published (web): December 27, 2016)

\begin{abstract}
The objective of the current study was to develop a bilayer tablet of Azithromycin containing both immediate and sustained layer and evaluate the effect of formulation variables on drug release. Thirty different formulations (F-1 to F-30) were prepared by direct compression. When the fraction of polymer was increased from $5.55 \%$ to $10 \%$, the rate of drug release was found to be slower. Maximum release of Azithromycin was from F-11 (within 8 hours), which contained $50 \mathrm{mg}(5.55 \%)$ of HPMC $50 \mathrm{cps}$. Slowest release was observed from F-30 containing $90 \mathrm{mg}(10 \%)$ of Carbopol $974 \mathrm{P}$. The IR spectral analysis revealed that all rate regarding agents and excipients used in this study are compatible with the active Azithromycin.
\end{abstract}

Key words: Azithromycin, bilayer tablet, HPMC, Carbopol, sustained release.

\section{INTRODUCTION}

Oral drug delivery has been known for decades as the most widely utilized route of administration among all the routes that have been explored for the systemic delivery of drugs. It remainsas the most favorable and preferred route of drug administration both by patient and physicians. ${ }^{1}$ The major challenge with the design of oral dosage forms lies with their poor bioavailability compared to injectable and implants. Pharmaceutical products intended for oral administration are cheaper and currently greater than sixty percent of drugs are marketed as oral products. ${ }^{2}$ Researchers and pharmaceutical companies are increasingly aware of the need for earlier assessment of new drug entities for their potential as oral candidates. $^{3}$ Usually conventional dosage form produce wide ranging fluctuation in drug concentration in the blood stream and tissues with

Correspondence to: Muhammad Rashedul Islam Tel: 88-01558299802; Fax: 88-02-8615583;

E-mail: rashed1505@yahoo.com

Dhaka Univ. J. Pharm. Sci. 15(2): 227-234, 2016 (December) consequent undesirable toxicity and poor efficiency. Many factors such as repetitive dosing and unpredictable absorption led to the concept of controlled drug delivery systems. The goal in designing sustained or controlled delivery systems is to reduce the frequency of dosing or to increase effectiveness of the drug by localization at the site of action, reducing the dose required or providing uniform drug delivery. The primary objective of sustained release drug delivery is to ensure safety and to improve efficacy of drugs as well as patient compliance. ${ }^{4} \mathrm{Bi}$-layer tablet is suitable for sequential release of two drugs in combination, separate two incompatible substances and also for sustained release tablets in which one layer is immediate release as initial dose and second layer is maintenance dose. ${ }^{5}$

Here Azithromycin has been chosen as the experimental drug. Itis a semisynthetic macrolide antibiotic, which is commonly used for a wide variety 
of mild-to-moderate bacterial infections. Azithromycin is used to treat or prevent certain bacterial infections, most often those causing middle ear infections, strep throat, pneumonia, typhoid, and sinusitis. ${ }^{6}$

The present research work was undertaken with the aim to formulate bilayer tablets of Azithromycin through its incorporation of an oral dosage form by using a simple and easy-to-scale-up formulation strategy.

\section{MATERIALS AND METHODS}

General experimental procedures. Azithromycin was kindly provided by Eskayef Bangladesh Limited as a gift sample. Different grades of HPMC were collected from Colorcon Limited, India. Microcrystalline cellulose (Avicel PH 102), Lactose, Carbopol 934P and Carbopol 974P, Providone K 30 and Magnesium stearate were kind gifts from Nipa Pharmaceuticals Limited, Dhaka. Potassium dihydrogen phosphate, $\mathrm{HCl}(37 \%)$ of Merck (Germany) and purified water from our Research laboratory were used. Among the instruments and machineries, vernier caliper of Erweka (Germany), Shimadzu UV Spectrophotometer (Japan), hardness tester and dissolution tester were from Erweka (Germany), Pharmatest disintegration tester (Germany), mini drum blender of Cadmach Machinery (India), friability tester of Logan (USA), Hanna pH meter (Portugal), stainless steel sieve (Bangladesh) and Manesty 16 station compression machine (England) were used.

Preparation of bilayer tablets of Azithromycin. For layer I of Azithromycin immediate release tablet preparation, the active drug was weighed and placed into mortar and pestle for mixing. Then all materials were properly mixed for five minutes in one way direction. A coloring agent was used in this mixer for differentiation between the immediate and sustained layer. Then lubricant was added and mixed for two minutes and then placed for compression (Table 1).

Azithromycin sustained release layer were prepared by wet granulation method. ${ }^{7-8}$ The active ingredient, HPMC $\mathrm{K} 4 \mathrm{M}$ and microcrystalline cellulose were passed through mesh \# 40 and were mixed homogenously. Providone K30 was added as a binder to the above blend and was mixed to get a final coherent mass. Obtained coherent mass was passed through mesh \#20 to get desired granules. The granules were primarily air dried and were finally dried at $50^{\circ} \mathrm{C}$ until a constant loss on drying (LOD) reaches $3-4 \%$, analyzed by moisture analyzer. The whole blend of dried granules was lubricated and homogenously mixed by magnesium stearate and talc.

Table 1. Formulation of immediate release Azithromycin layer.

\begin{tabular}{lc}
\hline Ingredients & Amount (mg) \\
\hline Azithromycin & 400 \\
Microcrystalline cellulose & 96.4 \\
Providone K 30 & 15.6 \\
Mg stearate & 4.4 \\
Purified talc & 5.6 \\
Spectrocolquinoline yellow LK & 8.6 \\
\hline Total= & $\mathbf{5 2 5}$ \\
\hline
\end{tabular}

The bi-layered tablet compression was achieved using $8.00 \mathrm{~mm}$ flat punch on a 12-station rotary tablet machine. The sustained release Azithromycin granules were introduced first into the die cavity and a light pre-compression was imparted so that the layer gets uniformly distributed in the die cavity doesn't mix up with the other layer. Further, immediate release layer blend was added above the previously light pre-compressed sustained release layer and final compression was carried out with optimum compression force. ${ }^{9-10}$

To evaluate the formulation variables on the release rate of bilayer tablets of Azithromycin, formulations were prepared by using six different polymers i.e. HPMC K4M (F1 to F5) and HPMC $\mathrm{K} 15 \mathrm{M}$ (F6 to F10) in table 2, HPMC 50cps (F11 to F15) and HPMC 100cps (F16 to F20) in table 3, Carbopol 934P (F21 to F25) and Carbopol 974P (F26 to F30) in table 4, as hydrophilic polymers. All the preparations were then stored in airtight containers at room for further study. 
Evaluation of physical properties of the prepared tablets. All prepared bilayer tablets were evaluated for its uniformity of weight, hardness, friability and thickness according to official methods. The weight variation was determined by taking 20 tablets selected randomly using an electronic balance. Tablet thickness was measured by vernier caliper. Tablet hardness was determined for 10 tablets using a Monsanto tablet hardness tester. Friability was determined by testing 10 tablets in a friability tester for 4 minutes at $25 \mathrm{rpm}$.

In the present experiment, the flow properties of the excipients have been evaluated. Bulk density, tapped density, Carr's compressibility index and Hausner's ratio have been calculated and presented in table 1. It was found that all the individual excipients and the mixture had the flow parameters within the range allowing desirable flow property

Table 2. Formulation of sustained release Azithromycin layer containing HPMC K4M and 15M.

\begin{tabular}{|c|c|c|c|c|c|c|c|c|c|c|}
\hline \multirow{2}{*}{$\begin{array}{l}\text { Ingredients } \\
(\mathrm{mg} / \mathrm{tab})\end{array}$} & \multicolumn{10}{|c|}{ Formulation code } \\
\hline & $\mathrm{F} 1$ & F2 & F3 & F4 & F5 & F6 & F7 & F8 & F9 & F10 \\
\hline Azithromycin & 250 & 250 & 250 & 250 & 250 & 250 & 250 & 250 & 250 & 250 \\
\hline HPMC K4M & 50 & 60 & 70 & 80 & 90 & 0 & 0 & 0 & 0 & 0 \\
\hline HPMC K15M & 0 & 0 & 0 & 0 & 0 & 50 & 60 & 70 & 80 & 90 \\
\hline $\begin{array}{l}\text { Microcrystalline } \\
\text { cellulose }\end{array}$ & 60 & 50 & 40 & 30 & 20 & 60 & 50 & 40 & 30 & 20 \\
\hline Providone K30 & 9 & 9 & 9 & 9 & 9 & 9 & 9 & 9 & 9 & 9 \\
\hline Mg stearate & 2.5 & 2.5 & 2.5 & 2.5 & 2.5 & 2.5 & 2.5 & 2.5 & 2.5 & 2.5 \\
\hline Purified talc & 3.5 & 3.5 & 3.5 & 3.5 & 3.5 & 3.5 & 3.5 & 3.5 & 3.5 & 3.5 \\
\hline Total $=$ & 375 & 375 & 375 & 375 & 375 & 375 & 375 & 375 & 375 & 375 \\
\hline
\end{tabular}

Table 3. Formulation of sustained release Azithromycin layer containing HPMC 50 cps and HPMC 100 cps.

\begin{tabular}{lcccccccccc}
\hline Ingredients $(\mathrm{mg} / \mathrm{tab})$ & \multicolumn{10}{c}{ Formulation code } \\
\cline { 2 - 10 } & F11 & F12 & F13 & F14 & F15 & F16 & F17 & F18 & F19 & F20 \\
\hline Azithromycin & 250 & 250 & 250 & 250 & 250 & 250 & 250 & 250 & 250 & 250 \\
HPMC 50 cps & 50 & 60 & 70 & 80 & 90 & 0 & 0 & 0 & 0 & 0 \\
HPMC 100 cps & 0 & 0 & 0 & 0 & 0 & 50 & 60 & 70 & 80 & 90 \\
Microcrystalline cellulose & 60 & 50 & 40 & 30 & 20 & 60 & 50 & 40 & 30 & 20 \\
Providone K30 & 9 & 9 & 9 & 9 & 9 & 9 & 9 & 9 & 9 & 9 \\
Mg stearate & 2.5 & 2.5 & 2.5 & 2.5 & 2.5 & 2.5 & 2.5 & 2.5 & 2.5 & 2.5 \\
Purified talc & 3.5 & 3.5 & 3.5 & 3.5 & 3.5 & 3.5 & 3.5 & 3.5 & 3.5 & 3.5 \\
\hline Total= & $\mathbf{3 7 5}$ & $\mathbf{3 7 5}$ & $\mathbf{3 7 5}$ & $\mathbf{3 7 5}$ & $\mathbf{3 7 5}$ & $\mathbf{3 7 5}$ & $\mathbf{3 7 5}$ & $\mathbf{3 7 5}$ & $\mathbf{3 7 5}$ & $\mathbf{3 7 5}$ \\
\hline
\end{tabular}

Table 4. Formulation of sustained release Azithromycin layer containing Carbopol 934 P and Carbopol 974 P.

\begin{tabular}{lcccccccccc}
\hline Ingredients (mg/tab) & \multicolumn{1}{c}{ Formulation code } \\
\cline { 2 - 10 } & F21 & F22 & F23 & F24 & F25 & F26 & F27 & F28 & F29 & F30 \\
\hline Azithromycin & 250 & 250 & 250 & 250 & 250 & 250 & 250 & 250 & 250 & 250 \\
Carbopol 934 P & 50 & 60 & 70 & 80 & 90 & 0 & 0 & 0 & 0 & 0 \\
Carbipol 974 P & 0 & 0 & 0 & 0 & 0 & 50 & 60 & 70 & 80 & 90 \\
Microcrystalline cellulose & 60 & 50 & 40 & 30 & 20 & 60 & 50 & 40 & 30 & 20 \\
Providone K30 & 9 & 9 & 9 & 9 & 9 & 9 & 9 & 9 & 9 & 9 \\
Mg stearate & 2.5 & 2.5 & 2.5 & 2.5 & 2.5 & 2.5 & 2.5 & 2.5 & 2.5 & 2.5 \\
Purified talc & 3.5 & 3.5 & 3.5 & 3.5 & 3.5 & 3.5 & 3.5 & 3.5 & 3.5 & 3.5 \\
\hline Total= & 375 & $\mathbf{3 7 5}$ & $\mathbf{3 7 5}$ & $\mathbf{3 7 5}$ & $\mathbf{3 7 5}$ & $\mathbf{3 7 5}$ & $\mathbf{3 7 5}$ & $\mathbf{3 7 5}$ & $\mathbf{3 7 5}$ & $\mathbf{3 7 5}$ \\
\hline
\end{tabular}


Measurement of physical properties of the prepared tablets.

Bulk density. Apparent bulk density (Db) was determined by pouring the blend into a graduated cylinder. The bulk volume $\left(\mathrm{V}_{\mathrm{b}}\right)$ and weight of the powder (W) was determined. ${ }^{7}$ The bulk density (Db) was calculated using following formula:

$\mathrm{Db}=\mathrm{W} / \mathrm{V}_{\mathrm{b}}$

Tapped density. The measuring cylinder containing a known mass of blend (W) was tapped for a fixed time (100 tapping). The minimum volume $\left(V_{t}\right)$ occupied in the cylinder and weight of the blend (W) was measured. ${ }^{8}$ The tapped density (Dt) was calculated using the formula, $\mathrm{Dt}=\mathrm{W} / \mathrm{V}_{\mathrm{t}}$.

Carr's compressibility index and Hausner's ratio. The Carr's compressibility index (also called as Carr's Consolidation index or Carr's Index) and Hausner's ratio can be calculated from the measured values of tapped density (Dt) and bulk density (Db), as follows ${ }^{9,10}$ :

Carr'scompressibility index $=(\mathrm{Dt}-\mathrm{Db}) / \mathrm{Dt} \mathrm{x} 100$

Hausner's ratio $=\mathrm{Dt} / \mathrm{Db}$

Angle of repose: Angle of repose was determined using funnel method. The blend was poured through a funnel that can be raised vertically until a maximum cone height (h) was obtained. ${ }^{11}$ Radius of the heap (r) was measured and angle of repose $(\theta)$ was calculated using the following formula, $\theta=\tan ^{-1}(\mathrm{~h} / \mathrm{r})$.

In vitro release studies of Azythromycin from the prepared tablets. The release rate of Azithromycin from tablets was determined using USP Type II (Rotating paddle method) dissolution testing apparatus. According to USP XXIII, the dissolution test was performed using $900 \mathrm{ml}$ of phosphate buffer as dissolution medium at $37 \pm$ $0.5^{\circ} \mathrm{Cand} 100 \mathrm{rpm}$. A sample of $10 \mathrm{ml}$ was withdrawn from the dissolution apparatus at predetermined time intervals of $0.30^{\text {th }}$ hour, $1^{\text {st }}$ hour, 2 nd hour, $3^{\text {rd }}$ hour, 4 th hour, $5^{\text {th }}$ hour, $6^{\text {th }}$ hour, $7^{\text {th }}$ hour and $8^{\text {th }}$ hour. The same volume of dissolution medium is replaced to maintain sink condition. Samples withdrawn were filtered through $0.45 \mu \mathrm{m}$ membrane filter and suitably diluted with phosphate buffer. Absorbance of these solutions was measured at $226 \mathrm{~nm}$ using a UV1800 SHIMADZU UV spectrophotometer. Cumulative percentage of drug release was calculated using an equation obtained from a standard curve. Dissolution rate was studied for all designed formulation.

Drug-excipient compatibility studies. The compatibility of drug with their respective excipients was studied by FT-IR spectroscopy. The IR spectra of both the drugs and the mixture of their excipients and their bilayer tablets were analyzed between wave numbers 4000 to $700 \mathrm{~cm}^{-1}$ (Figure 1).

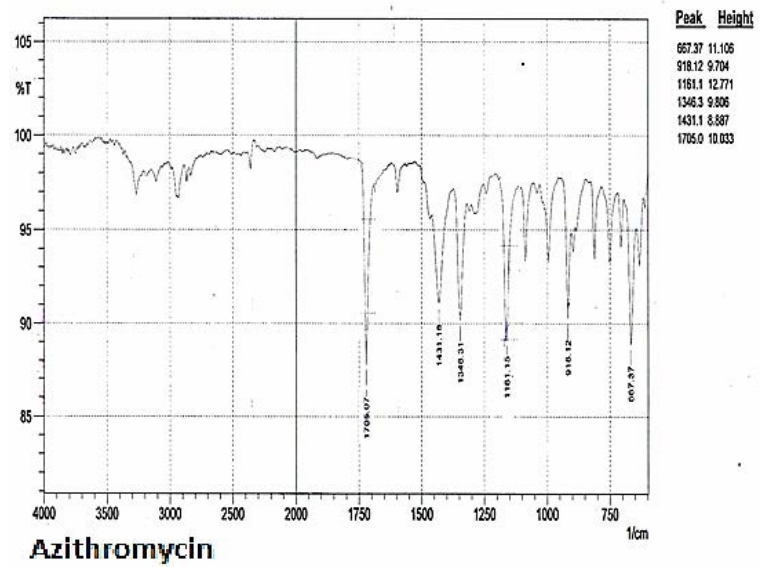

Figure 1. FT-IR spectrum of pure Azithromycin

Statistical analysis. In this study, one-way analysis of variance (ANOVA) (performed at 5\% significance level using SPSS, version 16.0) was used to compare the difference of dissolution profiles of the test matrix tablets.

\section{RESULTS AND DISCUSSION}

In the present study, thirty different formulations of bilayer tablets of Azithromycin were prepared by using six different polymers of HPMC K4M, HPMC K15M, Carbopol 934P, Carbopol 974P, HPMC 50cps and HPMC 100cps at the concentration of $5.55 \%$, $6.66 \%, 7.77 \%, 8.88 \%$ and $10 \%$ as rate retarding agent.

Analysis of physical properties. To evaluate the physical properties of the prepared tablets, we have 
determined the average weight, thickness, diameter, hardness and percent of friability of the HPMCK4M, HPMC K15M, Carbopol 934P, Carbopol 974P, HPMC 50cps and HPMC 100cps containing matrix tablets of Azithromycin (Table 5). We observed that the prepared Azithromycin tablets followed and met all the criteria specified in the monograph (Table 5).

Analysis of flow properties. In the present experiment, the flow properties of the excipients have been evaluated. Bulk density, tapped density, Carr's compressibility index and Hausner's ratio have been calculated and presented in table 6 . It was found that all the individual excipients and the mixture had the flow parameters within the range allowing desirable flow property.

Table 5. Physical properties of Azithromycin bilayer tablets.

\begin{tabular}{|c|c|c|c|c|c|}
\hline Formulation & $\begin{array}{l}\text { Average weight } \\
\text { (mg)* }\end{array}$ & $\begin{array}{c}\text { Average } \\
\text { thickness }(\mathrm{mm}) *\end{array}$ & $\begin{array}{c}\text { Average } \\
\text { diameter }(\mathrm{mm})^{*}\end{array}$ & $\begin{array}{c}\text { Average } \\
\text { hardness (kgf)* }\end{array}$ & $\begin{array}{c}\text { Friability } \\
(\%)\end{array}$ \\
\hline F-1 & $901.33 \pm 4.23$ & $7.11 \pm 0.04$ & $18.23 \pm 0.02$ & $15.17 \pm 1.25$ & 0.39 \\
\hline $\mathrm{F}-2$ & $902.03 \pm 5.33$ & $7.12 \pm 0.03$ & $18.23 \pm 0.01$ & $15.58 \pm 1.86$ & 0.11 \\
\hline F-3 & $901.5 \pm 3.94$ & $7.14 \pm 0.04$ & $18.22 \pm 0.02$ & $15.88 \pm 1.96$ & 0.12 \\
\hline F-4 & $901.83 \pm 4.07$ & $7.11 \pm 0.02$ & $18.23 \pm 0.02$ & $15.83 \pm 1.63$ & 0.42 \\
\hline F-5 & $898.33 \pm 5.72$ & $7.13 \pm 0.03$ & $18.23 \pm 0.02$ & $15.93 \pm 1.1$ & 0.13 \\
\hline F-6 & $901.83 \pm 3.82$ & $7.12 \pm 0.04$ & $18.24 \pm 0.01$ & $15.33 \pm 1.78$ & 0.05 \\
\hline $\mathrm{F}-7$ & $901.33 \pm 4.08$ & $7.14 \pm 0.04$ & $18.23 \pm 0.02$ & $15.87 \pm 1.74$ & 0.33 \\
\hline F-8 & $901.24 \pm 4.42$ & $7.13 \pm 0.04$ & $18.23 \pm 0.02$ & $15.62 \pm 0.94$ & 0.38 \\
\hline F-9 & $902.68 \pm 3.79$ & $7.13 \pm 0.03$ & $18.22 \pm 0.01$ & $15.95 \pm 1.17$ & 0.11 \\
\hline $\mathrm{F}-10$ & $900.33 \pm 3.93$ & $7.13 \pm 0.02$ & $18.23 \pm 0.01$ & $15.75 \pm 1.26$ & 0.18 \\
\hline F-11 & $901.67 \pm 4.08$ & $7.13 \pm 0.04$ & $18.23 \pm 0.02$ & $15.95 \pm 1.54$ & 0.23 \\
\hline F-12 & $898.33 \pm 1.75$ & $7.12 \pm 0.03$ & $18.23 \pm 0.02$ & $15.83 \pm 1.31$ & 0.25 \\
\hline F-13 & $900.89 \pm 3.69$ & $7.13 \pm 0.03$ & $18.23 \pm 0.02$ & $16.05 \pm 1.17$ & 0.22 \\
\hline F-14 & $899.21 \pm 5.4$ & $7.12 \pm 0.05$ & $18.23 \pm 0.01$ & $15.97 \pm 1.55$ & 0.22 \\
\hline F-15 & $898.5 \pm 4.51$ & $7.14 \pm 0.03$ & $18.24 \pm 0.01$ & $16.25 \pm 1.75$ & 0.19 \\
\hline F-16 & $900.67 \pm 3.69$ & $7.13 \pm 0.04$ & $18.23 \pm 0.02$ & $16 \pm 1.23$ & 0.33 \\
\hline F-17 & $899.78 \pm 4.73$ & $7.11 \pm 0.04$ & $18.24 \pm 0.02$ & $16.25 \pm 1.69$ & 0.36 \\
\hline F-18 & $898.67 \pm 1.63$ & $7.14 \pm 0.03$ & $18.23 \pm 0.02$ & $15.13 \pm 0.74$ & 0.22 \\
\hline F-19 & $901.39 \pm 4.24$ & $7.12 \pm 0.04$ & $18.23 \pm 0.01$ & $16.77 \pm 1.21$ & 0.19 \\
\hline F-20 & $900.33 \pm 2.94$ & $7.12 \pm 0.02$ & $18.23 \pm 0.02$ & $15.7 \pm 0.99$ & 0.22 \\
\hline $\mathrm{F}-21$ & $898.24 \pm 5.44$ & $7.13 \pm 0.05$ & $18.23 \pm 0.02$ & $16.63 \pm 1.33$ & 0.37 \\
\hline $\mathrm{F}-22$ & $901.50 \pm 4.64$ & $7.14 \pm 0.05$ & $18.23 \pm 0.02$ & $16.07 \pm 1.22$ & 0.35 \\
\hline F-23 & $900.69 \pm 4.43$ & $7.12 \pm 0.05$ & $18.23 \pm 0.02$ & $15.85 \pm 1.38$ & 0.21 \\
\hline F-24 & $901.87 \pm 4.38$ & $7.12 \pm 0.02$ & $18.24 \pm 0.02$ & $16.2 \pm 1.66$ & 0.25 \\
\hline F-25 & $901.17 \pm 4.12$ & $7.11 \pm 0.01$ & $18.24 \pm 0.02$ & $15.92 \pm 1.55$ & 0.16 \\
\hline F-26 & $900.33 \pm 4.51$ & $7.12 \pm 0.02$ & $18.24 \pm 0.02$ & $16.23 \pm 1.02$ & 0.13 \\
\hline $\mathrm{F}-27$ & $900.67 \pm 4.08$ & $7.13 \pm 0.02$ & $18.23 \pm 0.02$ & $15.97 \pm 1.69$ & 0.17 \\
\hline F-28 & $898.83 \pm 4.79$ & $7.12 \pm 0.03$ & $18.23 \pm 0.02$ & $16.43 \pm 1.18$ & 0.32 \\
\hline F-29 & $900.17 \pm 3.43$ & $7.14 \pm 0.03$ & $18.24 \pm 0.02$ & $15.97 \pm 1.69$ & 0.25 \\
\hline F-30 & $902.97 \pm 3.69$ & $7.11 \pm 0.02$ & $18.23 \pm 0.01$ & $16.58 \pm 1.32$ & 0.29 \\
\hline
\end{tabular}


Table 6. Characteristics of powder formulations.

\begin{tabular}{|c|c|c|c|c|c|}
\hline Formulation & $\begin{array}{l}\text { Bulk density } \\
(\mathrm{gm} / \mathrm{ml})\end{array}$ & $\begin{array}{l}\text { Tapped } \\
\text { density } \\
(\mathrm{gm} / \mathrm{ml})\end{array}$ & $\begin{array}{c}\text { Compressibility Index } \\
(\%)\end{array}$ & Hausner's ratio & $\begin{array}{l}\text { Angle of } \\
\text { repose }\end{array}$ \\
\hline F-1 & 0.523 & 0.561 & 6.77 & 1.07 & 22.5 \\
\hline F-2 & 0.542 & 0.582 & 6.87 & 1.07 & 23.1 \\
\hline F-3 & 0.533 & 0.571 & 6.65 & 1.07 & 22.1 \\
\hline F-4 & 0.556 & 0.597 & 6.87 & 1.07 & 22.8 \\
\hline F-5 & 0.543 & 0.586 & 7.34 & 1.08 & 20.5 \\
\hline F-6 & 0.576 & 0.617 & 6.65 & 1.07 & 19.6 \\
\hline F-7 & 0.612 & 0.662 & 7.55 & 1.08 & 22.7 \\
\hline F-8 & 0.589 & 0.624 & 5.61 & 1.06 & 22.5 \\
\hline F-9 & 0.485 & 0.523 & 7.27 & 1.08 & 20.6 \\
\hline $\mathrm{F}-10$ & 0.477 & 0.511 & 6.65 & 1.07 & 21.3 \\
\hline F-11 & 0.525 & 0.556 & 5.58 & 1.06 & 22.3 \\
\hline F-12 & 0.540 & 0.575 & 6.09 & 1.06 & 22.9 \\
\hline F-13 & 0.531 & 0.563 & 5.68 & 1.06 & 21.7 \\
\hline F-14 & 0.555 & 0.591 & 6.09 & 1.06 & 23.1 \\
\hline F-15 & 0.539 & 0.573 & 5.93 & 1.06 & 21.3 \\
\hline F-16 & 0.570 & 0.613 & 7.01 & 1.08 & 20.1 \\
\hline F-17 & 0.605 & 0.639 & 5.32 & 1.06 & 22.3 \\
\hline F-18 & 0.581 & 0.619 & 6.14 & 1.07 & 21.9 \\
\hline F-19 & 0.576 & 0.615 & 6.34 & 1.07 & 21.5 \\
\hline $\mathrm{F}-20$ & 0.556 & 0.597 & 6.87 & 1.07 & 20.7 \\
\hline F-21 & 0.495 & 0.531 & 6.78 & 1.07 & 21.5 \\
\hline $\mathrm{F}-22$ & 0.510 & 0.556 & 8.27 & 1.09 & 21.9 \\
\hline F-23 & 0.512 & 0.549 & 6.74 & 1.07 & 19.9 \\
\hline F-24 & 0.499 & 0.552 & 9.60 & 1.11 & 23.2 \\
\hline F-25 & 0.522 & 0.568 & 8.10 & 1.09 & 21.2 \\
\hline F-26 & 0.521 & 0.569 & 8.44 & 1.09 & 22.5 \\
\hline F-27 & 0.513 & 0.545 & 5.87 & 1.06 & 20.9 \\
\hline F-28 & 0.500 & 0.533 & 6.19 & 1.07 & 21.3 \\
\hline F-29 & 0.568 & 0.601 & 5.49 & 1.06 & 19.6 \\
\hline F-30 & 0.569 & 0.611 & 6.87 & 1.07 & 20.5 \\
\hline
\end{tabular}

Table 7. In vitro dissolution data from formulations F1 to F30 of Azithromycin tablets.

\begin{tabular}{|c|c|c|c|c|c|c|c|c|c|c|}
\hline $\begin{array}{c}\text { Polymer } \\
\text { name }\end{array}$ & $\begin{array}{c}\text { For- } \\
\text { mula- } \\
\text { tion }\end{array}$ & $\begin{array}{c}\text { Drug release } \\
\text { with drug } \\
\text { polymer ratio } \\
1: 0.07(50 \mathrm{mg})\end{array}$ & $\begin{array}{l}\text { For- } \\
\text { mula- } \\
\text { tion }\end{array}$ & $\begin{array}{c}\text { Drug release } \\
\text { with drug } \\
\text { polymer ratio } \\
1: 0.09(60 \mathrm{mg})\end{array}$ & $\begin{array}{l}\text { For- } \\
\text { mula- } \\
\text { tion }\end{array}$ & $\begin{array}{c}\text { Drug release } \\
\text { with drug } \\
\text { polymer ratio } \\
1: 0.11(70 \mathrm{mg})\end{array}$ & $\begin{array}{l}\text { For- } \\
\text { mula- } \\
\text { tion }\end{array}$ & $\begin{array}{c}\text { Drug release } \\
\text { with drug } \\
\text { polymer ratio } \\
1: 0.12(80 \mathrm{mg})\end{array}$ & $\begin{array}{l}\text { For- } \\
\text { mula- } \\
\text { tion }\end{array}$ & $\begin{array}{c}\text { Drug release } \\
\text { with drug } \\
\text { polymer ratio } \\
\text { 1: } 0.14(90 \mathrm{mg}) \\
\end{array}$ \\
\hline $\begin{array}{l}\text { HPMC } \\
\text { K4M }\end{array}$ & $\mathrm{F} 1$ & $88.34 \%$, & F2 & $71.78 \%$ & F3 & $66.48 \%$ & F4 & $63.18 \%$ & F5 & $62.31 \%$ \\
\hline $\begin{array}{l}\text { HPMC } \\
\text { K15M }\end{array}$ & F6 & $86.35 \%$, & F7 & $72.71 \%$ & F8 & $64.28 \%$ & F9 & $62.04 \%$ & F10 & $66.67 \%$ \\
\hline $\begin{array}{l}\text { HPMC } \\
50 \mathrm{cps}\end{array}$ & F11 & $97.33 \%$, & F12 & $93.83 \%$ & F13 & $90.49 \%$ & F14 & $72.86 \%$ & F15 & $71.87 \%$ \\
\hline $\begin{array}{l}\text { HPMC } \\
100 \mathrm{cps}\end{array}$ & F16 & $96.34 \%$ & F17 & $94.84 \%$ & F18 & $87.49 \%$ & F19 & $70.86 \%$ & F20 & $73.83 \%$ \\
\hline $\begin{array}{l}\text { Carbopol } \\
934 \mathrm{P}\end{array}$ & F21 & $93.91 \%$, & F22 & $71.09 \%$ & F23 & $70.32 \%$ & F24 & $63.71 \%$ & $\mathrm{~F} 25$ & $61.09 \%$ \\
\hline $\begin{array}{l}\text { Carbopol } \\
974 \mathrm{P}\end{array}$ & F26 & $84.78 \%$, & F27 & $75.27 \%$ & F28 & $62.05 \%$ & F29 & $59.46 \%$ & F30 & $58.87 \%$ \\
\hline
\end{tabular}

In vitro release rate of Azithromycin from the prepared bilayer tablets. It was observed that use of different polymers influences the drug release patterns. Formulations were prepared with batches F1-F5 containing HPMC K4M, F6-F10 with HPMC K15M, F11-F15 containing Carbopol 934P, F16-F20 
containing Carbopol 947P, F21-F25 containing HPMC 50cps and F26-F30 containing HPMC $100 \mathrm{cps}$. The release pattern of Azithromycin was monitored up to eight hours. Maximum release of Azithromycin was observed from F-11 (within 8 hours) as it contained $50 \mathrm{mg}$ of HPMC $50 \mathrm{cps}$ with drug polymer ratio 1:0.07 and methyl cellulose 60 $\mathrm{mg}$. Slowest release was found from F-30 which contained $90 \mathrm{mg}$ of Carbopol 974P with drug polymer ratio 1:0.14 with methyl cellulose $20 \mathrm{mg}$. It can be seen that with the increase of the polymer and decrease of the methyl cellulose the release of the drug also decrease, it means drug release retardation is directly proportional to the concentration of the polymer and inversely proportional with methyl cellulose. Drug release with drug polymer ratio is shown in the table 6. In this study, optimum rate retarding action was obtained by incorporating $90 \mathrm{mg}$ of Carbopol 974P $>$ HPMC K15M $>$ Carbopol 934P $>$ HPMC K4M $>$ HPMC 50cps $>$ HPMC 100cps.
On the other hand, maximum drug release was obtained by incorporating $50 \mathrm{mg}$ of HPMC $50 \mathrm{cps}>$ HPMC 100 cps>Carbopol 934P> HPMC K4M> HPMC K15M $>$ Carbopol 974P. It was found that, some polymers which allows fast release of drug at a lowest concentration, may produce significant drug retardation capability with the increase of the concentration e.g. HPMC 50 cps shows fast release at $50 \mathrm{mg}$ concentration, but shows good retardation properties at $90 \mathrm{mg}$ concentration. If the polymer level is too low, a complete gel layer may not form. ${ }^{12}$ In most studies, increased polymer level in the formulation results in decreased drug-release rates. Higher polymer content in the matrix decreases the rate an extent of the drug release because of increased matrix strength and gel formation around the matrix. ${ }^{11-12}$ In the present study carbopol polymer shows greater and reliable drug retardation ability compared to HPMC polymer.

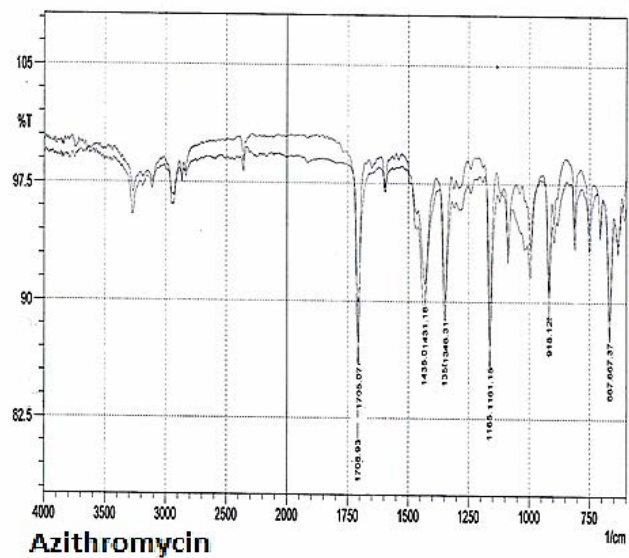

Figure 2. FT-IR spectrum of Azithromycin with HPMC.

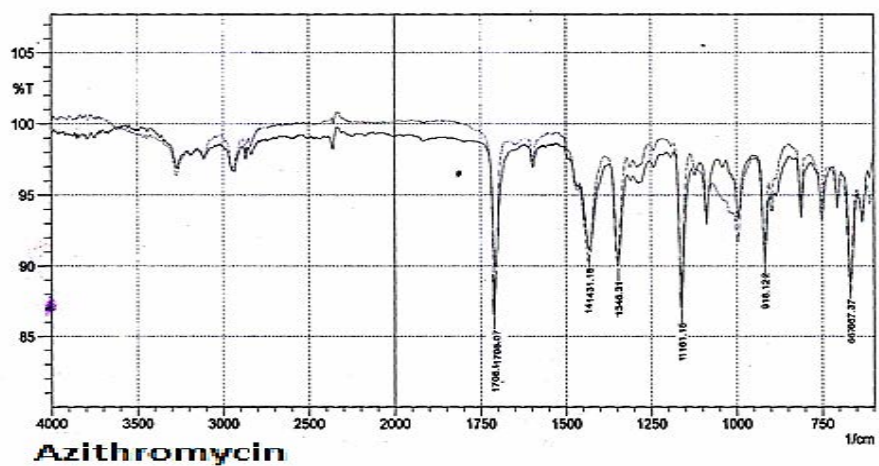

Figure 3. FT-IR spectrum of Azithromycin with Carbopol.

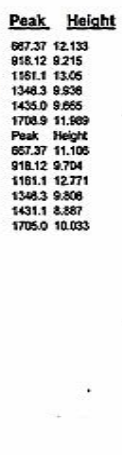


Drug-excipient compatibility studies by FTIR. As part of compatibility studies, FT-IR studies were performed as shown in figures 1-3 for the drug along with the excipients to detect any major interference between the drug and excipients. No incompatibilities were observed as evident from the IR spectra.

\section{CONCLUSION}

The study allowed us to develop new sustained formulation of Azithromycin by using different types of HPMC (HPMC K4M, HPMC K15M, HPMC 50cps and HPMC 100cps) and Carbopol (934P and 974P) to evaluate the effect of HPMC and Carbopol as rate controlling polymer. Further studies may be conducted by formulating new formulations with the combination of polymers of HPMC and carbopol to evaluate the combination efficacy of both polymers.

\section{REFERENCES}

1. Wong, S.M., Kellaway, I.W. and Murdan, S. 2006. Enhancement of the dissolution rate and oral absorption of a poorly water soluble drug by formation of surfactantcontaining microparticles. Int. J. Pharm. 317, 61-68.

2. Pretorius, E. and Bouic, P.J.D. 2009. Permeation of four oral drugs through human intestinal mucosa. AAPS. Pharm. Sci. Tech. 10, 270-275.

3. Davis, S.S. and Wilding, I.R. 2001. Oral drug absorption studies: the best model for man. Drug. Dis. Today. 6, 127130 .
4. Kumar, S., Gupta, V. and Malodia, K. 2012. Oral extended release drug delivery system: apromising approach. Asian. J. Pharm. Sci. 2, 38-43.

5. Bhavesh, S., Suresh, G. and Sanjay, S. 2008. Formulation and evaluation of bilayer tablet ofMetoclopramide Hydrochloride and Ibuprofen. AAPS. Pharma. Sci. Tech. 9, 818-827.

6. Patel, B.P. and Patel, D.M. 2016. Design of Core Compressed Tablets of Azithromycin and Bromhexine Hydrochloride as Dual Release System. Int. J. Pharm. Sci. Res. 7, 4055-4063.

7. Lachman L., Liberman, A. and Kinig, J.L. 1991.The Theory and Practice of Industrial Pharmacy. Varghese Publishing House, Bombay, $2^{\text {nd }}$ edn., pp. 67-68.

8. Longer, M.A. and Robinson, J.R. 1990. Remington's Pharmaceutical Sciences. Mack Publishing Company, Pennsylvania. $18^{\text {th }}$ edn., pp. 1675-1684.

9. Carr, R.L. 1965. Evaluating flow properties of Solids. Chem.Engin.72, 163-168.

10. Lindberg, N., Palsson, M., Pihl, A., Freeman R., Freeman, T., Zetzener, H., and Enstad, G. 2004.Flowability measurements of pharmaceutical powder mixtures with poor flow using five different techniques. Drug. Dev. Ind. Pharm. 30, 785-791.

11. Carter S.J. Cooper and Gunn's: Tutorial Pharmacy. 1986. CBS Publishers and Distributors, Delhi. $6^{\text {th }}$ edn., p.225.

12. Gupta, A.K. 1994. Introduction to Pharmaceutics-I. CBS publishers, Delhi. $3^{\text {rd }}$ edn., pp. 267-268.

13. Anilkumar, J.S., Manojkumar, S.P. and Harinath, N.M. 2010. Formulation and evaluation of gastro-retentive drug delivery system of selected anti-microbial agent. Indian J. Pharm. Educ. 44, 34-40. 